\title{
PARTIAL VP1 SEQUENCING OF BRAZILIAN INFECTIOUS BURSAL DISEASE VIRUS STRAINS
}

\author{
Maria Judite Bittencourt Fernandes ${ }^{*}$, Isabela Cristina Simoni ${ }^{1}$, Ricardo Harakava ${ }^{1}$, Eliana Borges Rivas ${ }^{1}$, Clarice Weis \\ Arns $^{2}$
}

${ }^{1}$ Instituto Biológico, São Paulo, Brazil; ${ }^{2}$ Instituto de Biologia, Universidade Estadual de Campinas, Campinas,SP, Brasil.

Submitted: March 01, 2011; Returned to authors for corrections: October 31, 2011; Approved: June 07, 2012.

\begin{abstract}
Infectious bursal disease virus (IBDV) is classified according to the antigenicity and virulence into classical virulent (cv), very virulent (vv), and antigenic variant strains. The molecular basis for the IBDV antigenic variation is well established and is associated to the capsid protein, VP2 (gene VP2 of segment A), whereas both VP2 and the RNA-dependent RNA polymerase, VP1 (gene VP1 of segment B), have been correlated with the virulence. In this study, seventeen Brazilian IBDV samples previously characterized by the VP2 gene as cv (three) and vv (fourteen) strains were genetically and molecularly analyzed for their VP1 gene. All of the strains kept with the same cv or vv classification except one sample, Br/03/DR. This sample was classified as Vv by its VP2 gene, but it was most closely related to the cv strains by its VP1 partial sequence and phylogeny. Studies on the phylogeny of VP1 have suggested a possible reassortment event that originated the vvVP1. In this case, the sample carrying vvVP2 and cvVP1 could be a descendant of IBDV ancestors prior to the reassortment of vvVP1; alternatively, it could be the result of a genetic exchange between the segments of different strains or with a live attenuated vaccine. Nevertheless, this is the first report of natural genetic reassortment of IBDV in Brazil.
\end{abstract}

Key words: Brazilian infectious bursal disease virus; very virulent strain; VP1; sequencing; phylogenetic analysis.

\section{INTRODUCTION}

Infectious bursal disease virus (IBDV) causes a disease among young chickens and is of great economic importance to the poultry industry worldwide with regard to both mortality and immunosuppression $(19,20,24)$. A member of the Birnaviridae family, IBDV contains a bisegmented dsRNA genome, designated $\mathrm{A}$ and $\mathrm{B}$, within a non-enveloped icosahedral capsid of $60 \mathrm{~nm}$ in diameter. Segment A of the genome contains two partially overlapping open reading frames (ORFs). The first, small ORF encodes a $17 \mathrm{kD}$ nonstructural host membrane-associated protein, VP5, and the second, large ORF encodes a $110 \mathrm{kD}$ polyprotein that is autoprocessed to produce the precursor of VP2 (pVP2), the multifunctional protein, VP3, and the viral protease, VP4. pVP2 is further processed to generate the outer capsid protein, VP2, which contains antigenic epitopes that are responsible for the induction of neutralizing antibodies. The segment B of the

*Corresponding Author. Mailing address: Avenida Conselheiro Rodrigues Alves, 1252, CEP 04014-002, São Paulo, SP, Brazil, CP12898.; Tel.: +55 11 50871714 Fax: +55 11 5087-1791.; E-mail: judite@biologico.sp.gov.br 
genome encodes a $90 \mathrm{kD}$ VP1 protein with RNA-dependent RNA polymerase activity $(6,16,20,24,28)$.

Two distinct serotypes of IBDV are recognized (1 and 2). Only serotype 1 is pathogenic for chickens and is classified according to the antigenicity and/or pathogenicity in classical virulent (cv) strains, very virulent (vv) strains, antigenic variant strains, and attenuated strains $(3,25,28)$. The antigenic variation has been based on mutations in a hydrophilic hypervariable region of the VP2 gene $(4,7,20,23)$. More specifically, only a few amino acids (aa) in this region contribute effectively to the antigenicity (28). Although many reports have also considered the aa of this same region of VP2 as the determinants of virulence $(1,19,20,24,28)$, further studies on the VP1 gene demonstrated the contribution of this gene to the virulence of $\operatorname{IBDV}(2,17)$. Both genes could be associated with the pathogenicity of IBDVs, yet the virulence markers remain unknown. Yamaguchi et al. (29) and Le Noüen et al. (14), studying the full genomic sequences from segments $\mathrm{A}$ and $\mathrm{B}$, were able to define phylogenetically representative partial nucleotide sequences for use in molecular epidemiology studies. The purpose of this study was to analyze the partial sequences and phylogeny of Brazilian IBDV samples, as based on one of the regions of the VP1 gene, previously characterized as cv and vV strains by the partial sequence of VP2 (8).

\section{MATERIALS AND METHODS}

\section{Field Strains}

The bursae of Fabricius were collected from commercial layer and broiler chickens from São Paulo and Paraná States, Brazil, between 1997 and 2004. The tissues were previously prepared, and identified as IBDV (8) (Table 1).

\section{Reverse transcription and polymerase chain reaction (RT/PCR)}

The viral RNA from the bursal homogenates was extracted using the QIAamp Viral RNA Kit (Qiagen Inc., Valencia, CA) according to the manufacturer's instructions.
The primer pair used for the partial amplification of a $594 \mathrm{bp}$ fragment of the VP1 gene (nts 290 to 883) is described in Le Noüen et al. (15). The amplification conditions were adapted from Hernández et al. (10) for a one-tube procedure using the AccessQuick ${ }^{\mathrm{TM}}$ RT-PCR System (Promega, Madison, WI) and a Perkin-Elmer Co. (Norwalk, CT) thermal cycler. An aliquot of $5 \mu \mathrm{l}$ of viral dsRNA was mixed with $4.5 \mu \mathrm{l}$ of ultra-pure water, denatured by boiling for $5 \mathrm{~min}$ at $98^{\circ} \mathrm{C}$, and immediately immersed in ice for $5 \mathrm{~min}$. The following mixture was then added to the tube: $12.5 \mu \mathrm{l}$ of AccessQuick Master Mix (2x), 1 $\mu \mathrm{l}$ of each primer and $1 \mu \mathrm{l}$ of AMV reverse transcriptase. The cDNA was synthesized at $42^{\circ} \mathrm{C}$ for $60 \mathrm{~min}$, and the amplification included an initial denaturation step $(5 \mathrm{~min}$ at $95^{\circ} \mathrm{C}$ ) and 35 cycles of $95^{\circ} \mathrm{C}$ for $30 \mathrm{sec}, 55^{\circ} \mathrm{C}$ for $1 \mathrm{~min}$ and $72^{\circ} \mathrm{C}$ for $1 \mathrm{~min}$. A final extension was performed at $72^{\circ} \mathrm{C}$ for 5 min. The PCR products were subjected to electrophoresis through a $1.5 \%$ agarose gel supplemented with $1 \%$ ethidium bromide.

\section{Nucleotide sequence and phylogenetic analysis}

The PCR products were purified using a PCR Purification Kit (Promega) and were sequenced using Big Dye Terminator Cycle Sequencing Ready Reaction (Applied Biosystems) and an ABI 377 automatic DNA sequencer. The sequences were aligned using Clustal $\mathrm{X}$ and subjected to a BLAST search, and the phylogenetic analysis was performed using the distance based neighbor-joining (NJ) method with the Kimura twoparameter option in PAUP 4.0 with 1,000 bootstrap replicates. Nucleotide accession numbers of the samples and the strains used for the comparison are shown in Table 1.

\section{RESULTS}

A fragment of the VP1 gene, between the clusters a and b, that is representative of the region used for phylogenetic analysis was successfully amplified in the seventeen Brazilian IBDV samples from our previous study (Table 1). The nucleotide (nt) and amino acid (aa) sequences were compared 
among the samples and with those of the vaccine strains and other reported IBDV strains. The three previous cvVP2 IBDV samples were also classified as cv strains using the VP1 aa sequences. In thirteen of the samples identified as vvVP2, all of the four common and characteristic aa substitutions of the vv strains within the VP1 fragment were found (Table 2): the TDN tripeptide between aa 145-147 and 242E. The exception was the Br/03/DR sample that presented the conserved aa of the cv strains in these positions.

Table 1. Description of infectious bursal disease virus strains used in this study .

\begin{tabular}{|c|c|c|c|}
\hline \multirow[t]{2}{*}{ Strain } & \multirow[t]{2}{*}{ Origin/Year } & \multicolumn{2}{|c|}{ VP1 Gene } \\
\hline & & Pathotype $^{\text {B }}$ & Accession number \\
\hline $\mathrm{Br} / 97 / \mathrm{BA}^{\mathrm{A}}$ & Brazil/1997 & $\mathrm{cV}$ & HQ602714 \\
\hline $\mathrm{Br} / 00 / \mathrm{BS}^{\mathrm{A}}$ & Brazil/2000 & vV & HQ602722 \\
\hline $\mathrm{Br} / 01 / \mathrm{BGK}^{\mathrm{A}}$ & Brazil/2001 & VV & HQ602718 \\
\hline $\mathrm{Br} / 01 / \mathrm{BGS}^{\mathrm{A}}$ & Brazil/2001 & vV & HQ602719 \\
\hline $\mathrm{Br} / 01 / \mathrm{BJM}^{\mathrm{A}}$ & Brazil/2001 & VV & HQ602720 \\
\hline $\mathrm{Br} / 01 / \mathrm{BNK}^{\mathrm{A}}$ & Brazil/2001 & vV & HQ602721 \\
\hline $\mathrm{Br} / 01 / \mathrm{CA}^{\mathrm{A}}$ & Brazil/2001 & vV & \\
\hline $\mathrm{Br} / 01 / \mathrm{CB}^{\mathrm{A}}$ & Brazil/2001 & vV & HQ602723 \\
\hline $\mathrm{Br} / 01 / \mathrm{CC}^{\mathrm{A}}$ & Brazil/2001 & vV & HQ602724 \\
\hline $\mathrm{Br} / 03 / \mathrm{CK}^{\mathrm{A}}$ & Brazil/2003 & vV & HQ602725 \\
\hline $\mathrm{Br} / 03 / \mathrm{DB}^{\mathrm{A}}$ & Brazil/2003 & vV & HQ602727 \\
\hline $\mathrm{Br} / 03 / \mathrm{DQ}^{\mathrm{A}}$ & Brazil/2003 & VV & HQ602728 \\
\hline $\mathrm{Br} / 03 / \mathrm{DR}^{\mathrm{A}}$ & Brazil/2003 & reassortant & HQ602717 \\
\hline $\mathrm{Br} / 03 / \mathrm{DU}^{\mathrm{A}}$ & Brazil/2003 & VV & HQ602729 \\
\hline $\mathrm{Br} / 04 / \mathrm{CR}^{\mathrm{A}}$ & Brazil/2004 & vV & HQ602726 \\
\hline $\mathrm{Br} / 04 / \mathrm{DE}^{\mathrm{A}}$ & Brazil/2004 & $\mathrm{cV}$ & HQ602715 \\
\hline $\mathrm{Br} / 04 / \mathrm{DN}^{\mathrm{A}}$ & Brazil/2004 & $\mathrm{cv}$ & HQ602716 \\
\hline UK-661 & UK/1994 & vv & AJ878666 \\
\hline OKYM & Japan/1997 & vV & D49707 \\
\hline 99009 & Brazil/99 & vv & AJ878672 \\
\hline 94432 & France/1994 & vV & AJ878678 \\
\hline variant $\mathrm{A}$ & USA/1985 & variant & AJ878675 \\
\hline $\mathrm{Cu}-1 w t$ & German/1975 & $\mathrm{cV}$ & AJ878644 \\
\hline F52-70 & $\mathrm{UK} / 1970$ & $\mathrm{cv}$ & AJ878643 \\
\hline $23 / 82$ & Serotype $2 / 1985$ & avirulent & AJ878684 \\
\hline 02015.1 & Venezuela/2002 & reassortant & AJ878685 \\
\hline 02015.2 & Venezuela/2002 & reassortant & AJ878686 \\
\hline ZJ2000 & China/2000 & reassortant & DQ166818 \\
\hline SH95 & China/2003 & reassortant & AY 134875 \\
\hline 02015.1 & Venezuela/2002 & reassortant & AJ878685 \\
\hline CEVAC IBDL & vaccine & attenuated & AJ878660 \\
\hline D78 & vaccine & attenuated & AJ878654 \\
\hline $228 \mathrm{E}$ & vaccine & attenuated & AJ878657 \\
\hline Bursine 2 & vaccine & attenuated & AJ878655 \\
\hline
\end{tabular}

${ }^{\mathrm{A}}$ Brazilian samples obtained in this study.

Table 2. Amino acid (aa) exchanges within the VP1 fragment (68-248aa) in different infectious bursal disease virus strains.

\begin{tabular}{lccccc}
\hline & & \multicolumn{5}{c}{ aa at positions } \\
\cline { 3 - 6 } Strain & Pathotype & $\mathbf{1 4 5}$ & $\mathbf{1 4 6}$ & $\mathbf{1 4 7}$ & $\mathbf{2 4 2}$ \\
\hline $\mathrm{Cu}-1 \mathrm{wt}$ & $\mathrm{cv}$ & $\mathrm{N}$ & $\mathrm{E}$ & $\mathrm{G}$ & $\mathrm{D}$ \\
$\mathrm{F}-52 / 70$ & $\mathrm{cv}$ & $\mathrm{N}$ & $\mathrm{E}$ & $\mathrm{G}$ & $\mathrm{D}$ \\
$\mathrm{Br} / 01 / \mathrm{BJM}^{\mathrm{A}}$ & $\mathrm{cv}$ & $\mathrm{N}$ & $\mathrm{E}$ & $\mathrm{G}$ & $\mathrm{D}$ \\
99009 & $\mathrm{vv}$ & $\mathrm{T}$ & $\mathrm{D}$ & $\mathrm{N}$ & $\mathrm{E}$ \\
$\mathrm{UK} 661$ & $\mathrm{vv}$ & $\mathrm{T}$ & $\mathrm{D}$ & $\mathrm{N}$ & $\mathrm{E}$ \\
OKYM & $\mathrm{vv}$ & $\mathrm{T}$ & $\mathrm{D}$ & $\mathrm{N}$ & $\mathrm{E}$ \\
$\mathrm{Br} / 03 / \mathrm{DU}^{\mathrm{A}}$ & $\mathrm{vv}$ & $\mathrm{T}$ & $\mathrm{D}$ & $\mathrm{N}$ & $\mathrm{E}$ \\
02015.1 & reassortant & $\mathrm{T}$ & $\mathrm{E}$ & $\mathrm{S}$ & $\mathrm{D}$ \\
02015.2 & reassortant & $\mathrm{N}$ & $\mathrm{E}$ & $\mathrm{G}$ & $\mathrm{T}$ \\
$\mathrm{SH} 95$ & reassortant & $\mathrm{N}$ & $\mathrm{E}$ & $\mathrm{G}$ & $\mathrm{D}$ \\
ZJ2000 & reassortant & $\mathrm{T}$ & $\mathrm{D}$ & $\mathrm{N}$ & $\mathrm{E}$ \\
Br/03/DR & reassortant & $\mathrm{N}$ & $\mathrm{E}$ & $\mathrm{G}$ & $\mathrm{D}$ \\
variant A & variant & $\mathrm{N}$ & $\mathrm{E}$ & $\mathrm{G}$ & $\mathrm{D}$ \\
$\mathrm{D} 78,228 \mathrm{E}$ and Bursine 2 & vaccine & $\mathrm{N}$ & $\mathrm{E}$ & $\mathrm{G}$ & $\mathrm{D}$ \\
CEVAC & vaccine & $\mathrm{N}$ & $\mathrm{E}$ & $\mathrm{D}$ & $\mathrm{D}$ \\
23/82 & serotype 2 & $\mathrm{~N}$ & $\mathrm{E}$ & $\mathrm{G}$ & $\mathrm{D}$ \\
\hline
\end{tabular}


The identity percentages of the deduced aa sequence of the $\mathrm{Br} / 03 / \mathrm{DR}$ sample with the others strains were determined. The sequence of this sample showed a higher identity with our Brazilian (Br) cv samples (93.6\%-96.8\%) than with the vv samples (91.0\%-95.2\%). However, the $\mathrm{Br} / 03 / \mathrm{DR}$ sample had a $91.0 \%$ similarity to the sequences of the $\mathrm{cv}$ reference strains, $90.4 \%-91.0 \%$ to those of the vv strains and $91.5 \%-92.5 \%$ to the vaccine strains. Regarding the reassortant strains, our sample, Br/03/DR (vvVP2cvVP1), exhibited $92.0 \%$ similarity to the
SH95 (vvVP2cvVP1) and 90.4\% to the ZJ2000 (cvVP2vvVP1) strains. The phylogenetic tree of the predicted aa sequences of the VP1 gene fragment from our samples and the published IBDV strains is shown in Figure 1. Our vv samples branched together with the other vv strains and in a distinct cluster from the cv strains, which included our cv samples and the $\mathrm{Br} / 03 / \mathrm{DR}$ sample. This profile of the $\mathrm{Br} / 03 / \mathrm{DR}$ sample carrying vVVP2, but cvVP1, is indicative of a genetic reassortment.

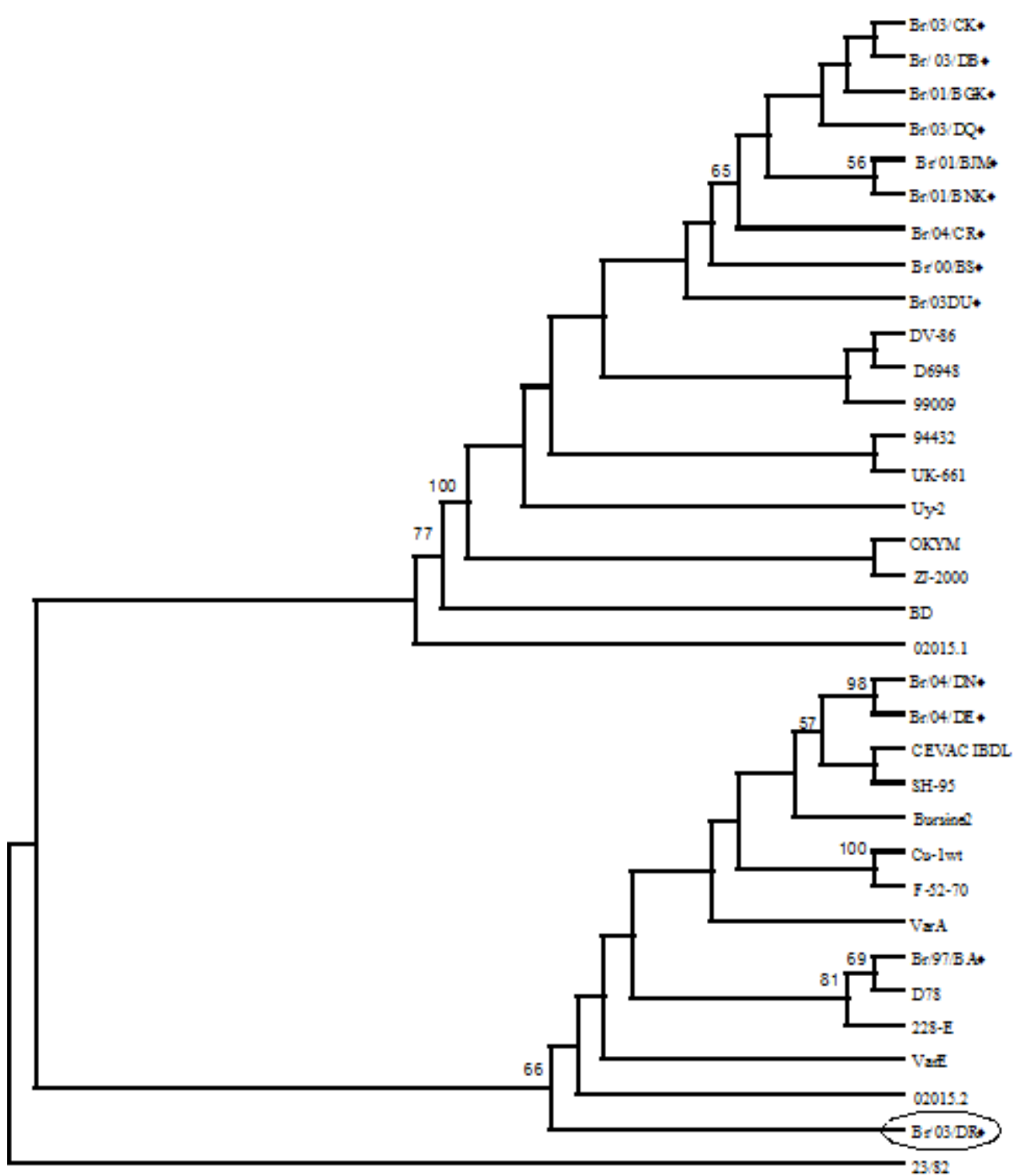

Figure 1. Phylogenetic tree of 13 Brazilian IBDV isolates (rhombus symbol), reference strains (cv and vv) and vaccines. The neighbor-joining analysis was based in predicted amino acid sequences of the fragment of the VP1 gene (aa 68-248) using the PAUP program. The bootstrap values were included in the branches since that $>50 \%$. 


\section{DISCUSSION}

The fundamental molecular basis for the pathogenicity of IBDV is not entirely clear and remains questionable. To understand the circulating viruses in Brazil better, we continued our studies of the Brazilian samples from a period of seven years, which were previously classified as $\mathrm{cv}$ or $\mathrm{vv}$ strains by analysis of the VP2 gene (8), focusing on the VP1 gene in this study. Through sequencing, comparative alignments and phylogeny of the VP1 gene, all samples maintained the previous cv and vv assignments, except one (Br/03/DR).

Studies involving the multiple, full-length sequencing of the VP1 gene of diverse vV strains and from different countries have revealed the presence of 17 common aa residues, with eight that are unique to these strains $(5,10,13,18,29)$. The $\mathrm{Br} / 03 / \mathrm{DR}$ sample was the sole vvIBDV strain that did not present these common aa. Conversely, it presented the conserved aa of the cvIBDV strains, residue E146, which Ren et al. (21) correlated to the attenuated virulence of the Chinese isolate, YS07, together with two other residues (4I and S687). However, these authors also correlated other unique mutations in the VP2 sequence to the low mortality of this isolate. The role of cvVP1 in virulence of our sample cannot yet be fully established because of the absence of in vivo studies and fulllength sequencing.

The phylogenetic tree constructed from the partial deduced aa sequences of VP1 showed that the Brazilian vvVP1 samples branched in a distinct cluster from the cvIBDV strains and even from the serotype 2 strain described in other studies $(5,12,29)$. Phylogenetic studies with the VP1 gene of the vvIBDV strains suggested that the B segment is genetically distinct from that of all other IBDV strains, suggesting that the origin of the vvIBDVs is a a genetic reassortment of an unidentified source $(1,12,29)$. Using the estimation of the time of emergence of the most recent common ancestor (TMRCA) and coalescence techniques in both genome segments to the IBDV, Hon et al. (11) verified that this segment B reassortment occurred in the mid-1980s, whereas the emergence of the vv A segment was 20 years prior. The authors concluded that the enhancement of virulence and the expansion of the vvIBDV strains in mid-1980s may be due to a synergistic effect of mutations on both of its genome segments. According to this conclusion, the $\mathrm{Br} / 03 / \mathrm{DR}$ sample presenting a B segment derived from a cvIBDV strain, but with the segment A of a vVIBDV strain (8), could be a descendant of the IBDV ancestors before the reassortment of segment B of vvVP1.

It is known that the use of vaccines with intermediate virulence to control the disease by the vv strains can be responsible for a partial immunosuppression and mild bursal lesions. Although the viral multiplication does not revert the virulence, it could be the source of a genetic exchange producing a natural reassortant virus. Therefore, there is the risk of using live vaccines with the generation of such reassortments $(26,27)$. It could be another explanation for the origin of the $\mathrm{Br} / 03 / \mathrm{DR}$ sample. Natural reassortments have mainly been described in China. The SH95 (20) and Gx (9) isolates and our Br/03/DR sample have vvVP2 and cvVP1. However, these two Chinese isolates maintained their virulence even without the vvVP1. Boot et al. (1) had initially verified that the VP1 gene would not have a major influence on the virulence of the vvIBDV strains. However, the ZJ2000 and TL2004 reassortants presented high virulence even without the presence of vvVP2 (cvVP2/vvVP1) $(26,27)$. In this case, the VP1 gene could be contributing to the enhanced virulence of these vvIBDVs, corroborating the further studies of Boot et al. (2).

High mutation rates occur in RNA viruses, but these variations are limited by functional constraints, and the rate of genomic reassortment events in nature is also low and depends on many factors. Gao et al. (9), in a quasispecies population study of the Gx isolate, found a much higher frequency of mutation in VP1 than in VP2, an unexpected result for a RNA 
polymerase. However, the most conserved region was correlated with another possible functional region. This isolate is also a reassortant, with VP2 derived from vvIBDV and VP1 from a cv strain and a retention of virulence. Studying more than 50 strains of IBDV of diverse years and localities, Le Noüen et al. (15) concluded that the co-evolution of both the A and $\mathrm{B}$ segments of IBDV is frequent, although they have also found a natural reassortant (strain 02015.1). Continuing studies of full-genome sequences and the pathogenicity in vivo are very important to understand the true role of VP1 in virulence and/or of the risk of the use of live vaccines and that will provide the exact relationship between the genetic composition and pathogenicity. Regardless, this is the first report of a natural genetic reassortment of IBDV strains in Brazil.

\section{REFERENCES}

1. Boot, H.J.; Agnes, A.; ter Huurne, A.A.; Hoekman, A.J.; Peeters, B.P.; Gielkens, A.L. (2000). Rescue of very virulent and mosaic infectious bursal disease from cloned cDNA: VP2 is not the sole determinant of the virulent phenotype. J. Virol. 74(15), 6701-6711.

2. Boot, H.J.; Hoekman, A.J.W.; Gielkens, A.L.J. (2005). The enhanced virulence of very virulent infectious bursal disease virus is partly determined by its B-segment. Arch. Virol. 150, 137-144.

3. Brandt, M; Yao, K; Liu, M; Heckert, R.A.; Vakharia, V.N. (2001). Molecular determinants of virulence, cell tropism, and pathogenic phenotype of infectious bursal disease virus. J. Virol. 75 (24), 1197411982.

4. Brown, M.D.; Green, P.; Skinner, A. (1994). VP2 sequences of recent European "very virulent" isolates of infectious bursal disease virus are closely related to each other but are distinct from those of "classical" strains. J. Gen. Virol. 75, 675-680.

5. Brown, M.D.; Skinner, M.A. (1996). Coding sequences of both genome segments of an European 'very virulent' infectious bursal disease virus. Virus Res. 40, 1-15.

6. Casanãs, A.; Navarro, A.; Ferrer-Orta, C.; González, D.; Rodríguez, J.F.; Verdaguer, N.(2008). Structural insights into the multifunctional protein VP3 of birnaviruses. Structure 16, 29-37.

7. Eterradosi, N.; Arnauld, C.; Toquin, D.; Rivallan, G. (1998). Critical amino acid changes in VP2 variable domain are associated with typical and atypical antigenicity in very virulent infectious bursal disease viruses. Arch. Virol.143, 1627-1636.

8. Fernandes, M.J.B.; Simoni, I.C.; Vogel, M.G.; Harakava, R.; Rivas,
E.B.; Oliveira, M.B. C.; Kanashiro, A.M.I.; Tessari, E.N.C.; Gama, N.M.S.Q.; Arns, C.W. (2009). Molecular characterization of Brazilian infectious bursal disease virus isolated from 1997 to 2005. Avian Dis. 53, 449-454.

9. Gao, H.L.; Wang, X.M.; Gao, Y.L.; Fu, C.Y. (2007). Direct evidence of reassortment and mutant spectrum analysis of a very virulent infectious bursal disease virus. Avian Dis. 51, 893-899.

10. Hernández, M.; Banda A.; Hernández, D.; Panzera, F.; Pérez, R. (2006). Detection of very virulent strains of infectious bursal disease virus (vvIBDV) in commercial broilers from Uruguay. Avian Dis. 50, 624631.

11. Hon, C.C.; Lam, T.Y.; Drummond, A.; Rambaut, A. Lee, Y.-F.; Yip, C.W.; Zeng, F.; Lam, P.-Y.; Ng, P.T.W.; Leung, F.C.C. (2006). Phylogenetic analysis reveals a correlation between the expansion of very virulent infectious bursal disease virus and reassortment of its genome segment B. J. Virol. 80, 8503-8509.

12. Islam, M.R.; Zierenberg, K.; Müller, H. (2001). The genome segment B encoding the RNA-dependent RNA polymerase protein VP1 of very virulent infectious bursal disease virus (IBDV is phylogenetically distinct from that of all other IBDV strains. Arch. Virol. 146, 2481-2492.

13. Kong, L.L.; Omar, A.R.; Hair-Bejo, M.; Aini, I.; Seow, H.F. (2004). Sequence analysis of both genome segments of two very virulent infectious bursal disease virus field isolates with distinct pathogenicity. Arch. Virol. 149, 425-434.

14. Le Noüen, C.; Rivallan, G.; Toquin, D.; Eterradossi, N. (2005). Significance of the genetic relationships deduced from partial nucleotide sequencing of infectious bursal disease virus genome segments A or B. Arch.Virol. 150, 313-325.

15. Le Noüen, C.; Rivallan, G.; Toquin, D.; Darlu, P.; Morin, Y.; Beven, V.; Boisseson, C.; Cazaban, C.; Comte, S.; Gardin, Y.; Eterradossi, N. (2006). Very virulent infectious bursal disease virus: reduced pathogenicity in a rare natural segment B-reassorted isolate. J. Gen. Virol. 87, 209-216.

16. Letzel, T.; Coulibaly,F.; Rey, F.A.; Delmas, B.; Jagt, E.; van Loon, A. A. M. W.; Mundt, E. (2007). Molecular and structural bases for the antigenicity of VP2 of infectious bursal disease virus. J.Virol. 81(23): 12827-12835.

17. Liu, M.; Vakharia, V.N. (2004). VP1 protein of infectious bursal disease virus modulates the virulence in vivo. Virology 330, 62-73.

18. Lojkíc, I.; Bidin, Z.; Pokríc, B. (2008). Sequence analysis of both genome segments of three Croatian infectious bursal disease field viruses. Avian Dis. 52, 513-519.

19. Müller, H.; Islam, R.; Raue, R. (2003) Research on infectious bursal disease - the past, the present and the future. Vet. Microbiol. 97, 153165.

20. Nagarajan, M.M.; Kibenge, F.S.B. (1997). Infectious bursal disease virus: a review of molecular basis for variations in antigenicity and 
virulence. Can. J. Vet. Res. 61, 81-88.

21. Ren, X.; Xue, C.; Zhang, Y.; Chen, F.; Cao, Y. (2009). Genomic analysis of one Chinese strains YS07 of infectious bursal disease virus reveals unique genetic diversity. Virus Genes 39 (2), 246-248.

22. Sun, J.-H.; Lu, P.; Yan, Y-X; Hua, X.-G.; Jiang, J.; Zhao, Y. (2003). Sequence and analysis of genomic segment $\mathrm{A}$ and $\mathrm{B}$ of very virulent infectious bursal disease virus isolated from China. J. Vet. Med. B 50, 148-154.

23. Vakharia, V.N.; He, J.; Ahamed, B.; Snyder, D.B. (1994). Molecular basis of antigenic variation in infectious bursal disease virus. Virus Res. 31, 265-273.

24. Van den Berg, T.P. (2000). Acute infectious bursal disease in poultry: a review. Avian Pathol. 29, 175-194.

25. Van den Berg, T.P.; Morales, D.; Eterradossi, N.; Rivallan, G.; Toquin, D.; Raue, R.; Zierenberg, K.; Zhang, M.F.; Zhu, Y.P.; Wang, C.Q.;
Zheng, H.J.; Wang, X.; Chen, G.C.; Lim, B.L.; Müller, H. (2004). Assessment of genetic, antigenic and pathotypic criteria for the characterization of IBDV strains. Avian Pathol. 33, 470-476.

26. Wei, Y.; Li, J.; Zheng, J.; Xu, H.; Li, L.; Yu, L. (2006). Genetic reassortment of infectious bursal disease virus in nature. $B B R C, 350$, 277-287.

27. Wei, Y.; Yu, S.; Zheng, J.; Chu, W.; Xu, H.; Yu, S.; Yu, L. (2008). Reassortment infectious bursal disease virus isolated in China. Virus Res. 131, 279-282.

28. Wu, C.C.; Rubinelli, P.; Lin, T. L. (2007). Molecular detection and differentiation of infectious bursal disease virus. Avian Dis. 51, 515-526.

29. Yamaguchi, T.; Ogawa, M.; Miyoshi, M.; Inoshima, M.; Fukushi, H.; Hirai, H. (1997). Sequence and phylogenetic analysis of highly virulent infectious bursal disease virus. Arch. Virol. 142, 1441-1458. 